\title{
MEDICAL EDUCATION IS CHANGING IN PAKISTAN
}

\author{
Iftikhar Ahmad \\ Department of Community Medicine, Gomal Medical College, D.I.Khan, Pakistan
}

In 1910, Flexner report was published accusing the incompetent American, apprenticeship-based, medical education system. This system was producing low-grade physicians, with poor teaching and training standards in medical schools. ${ }^{1}$ The post-Flexnarian, discipline-based system transformed the structure of medical education in US, Canada and UK, by establishing the gold standard; the biomedical model of medical training. It became one of the most important revelations in the history of medicine and a foundation for the upcoming problem-based and clinical presentation based models of medical curricula. ${ }^{2}$

In Pakistan, medical education is improving. More and more teachers are becoming qualified in medical education courses. They are becoming aware of concept-building, creative thinking, self-directed lifelong learning, clinical reasoning and evidence-based learning. ${ }^{3}$

There is a strong need to involve all the stakeholders including teachers, students, patients, society and government in the process of curriculum planning, development and implementation. Medical students should be taught keeping in view the exit outcomes of knowledge, skills and attitudes, based on the adult learning principles. As per social constructivist learning theory, they need to be stimulated to create their own understanding. Community-based learning (CBL), based on the health needs of the individuals, families, and community is the real solution to the health problems of our area. Lack of emphasis on research has made Pakistani doctors, lagging far behind the medical graduates of other countries intellectually. The doctors are now taking more interest in publishing their research papers in the prestigious research journals inside the country as well as across the globe. Research is a national investment for solving plethora of health problems, with no immediate reward. ${ }^{4}$

Pakistan should also annually review the responsibilities of doctors, students and medical institutes for the improvements in the health system on the pattern of General Medical Council, UK. Clearly; there is a need for strong academic and visionary leadership in our medical institutes. ${ }^{5-8}$

Educational methods and equipment need to be provided to produce the desired knowledge, skills and attitudes in medical graduates to provide the community with seven star doctor, who is a care provider, medical knowledge expert, leader/ manager, communicator, community health promoter, researcher and a true professional. ${ }^{9}$

In Pakistan, the medical institutions are observing a paradigm shift based on SPICES model. SPICES attributes of problem-based, integrated, studentcentered, community-based, systematic teaching \& learning and electives are replacing the traditional information gathering, discipline-based, teachercentered, hospital-based, opportunistic and uniform learning respectively. ${ }^{10}$

Pakistan Medical Commission has made it mandatory for all the medical institutions to establish departments of medical education for planning, implementing \& evaluating teaching, training and research activities in their respective institutes. We are improving in medical education, though not at a satisfactory speed. We have the resources and the untapped potential. Medical education in Pakistan is standing at the cross roads. We hope things will continue to be better and in a much faster way to compete the contemporary world in the field of medical education.

KEY WORDS: Education; Universities; Curriculum; Knowledge; Attitude.

Cite as: Ahmad I. Medical education is changing in Pakistan [editorial]. Gomal J Med Sci 2020 Oct-Dec; 18 (4):13940. http://doi.org/10.46903/gjms/18.04.906

\section{Corresponding Author:}

Professor Dr. Iftikhar Ahmad

Department of Community Medicine

Gomal Medical College, D.I.Khan, Pakistan

E-mail: iftikharahmadgandapur66@gmail.com

Date Submitted:

20-07-2020

Date Revised:

$09-08-2020$

Date Accepted:

\section{REFERENCES}

1. Duffy TP. The Flexner report-100 years later. Yale J Biol Med 2011 Sep; 84(3): 269-76.

2. Fleming KA. Flexner at 100: a brief view from Oxford. Perspect Biol Med 2011 Winter; 54(1):24-9. https://doi.org/10.1353/pbm.2011.0013

3. Latif MZ, Wajid G. Reforming medical education in Pakistan through strengthening departments of medical education. Pak J Med Sci 2018 NovDec; 34(6):1439-44. https://doi.org/10.12669/ pjms.346.15942 
4. Brauer DG, Ferguson KJ. The integrated curriculum in medical education: AMEE Guide No. 96. Med Teach 2015 Apr; 37(4):312-22. https://doi.or $\mathrm{g} / 10.3109 / 0142159 X .2014 .970998$

5. Nasim M. Medical education needs to change in Pakistan. J Pak Med Assoc 2011 Aug; 61 (8):808-11.

6. Khan UA, Ayub R, Ayub JU, Khan AR, Ahsan J. Evaluation of MBBS curriculum using spices model. J Med Sci 2015 Oct-Dec; 23(4):248-50.

7. Majeed A. An Overview of medical education in Pakistan and the improvements required. Blog on J Pioneering Med Sci Blogs 2012 Aug 21 [cited 2020 Jun 12]. Available at: https:// blogs.jpmsonline.com/2012/08/21/an-overviewof-medical-education-in-pakistan-and-theimprovements-required/
8. Iqbal MP, Waqar MA. Basic medical research as a means of solving national health problems. J Pak Med Assoc 1995; 45(9):250-2.

9. Siddiqui F, Malik AA. Promoting self-regulated learning skills in medical students is the need of time. J Taibah Univ Med Sci 2019 May 3; 14(3):277-81. https://doi.org/10.1016/j. jtumed.2019.03.003

10. Khan H, Taqui AM, Khawaja MR, Fatmi Z. Problem-based versus conventional curricula: influence on knowledge and attitudes of medical students towards health research. PLoS One 2007 Jul 18; 2(7):e632. https://doi.org/10.1371/ journal.pone.0000632
CONFLICT OF INTEREST

Authors declare no conflict of interest. GRANT SUPPORT AND FINANCIAL DISCLOSURE None declared. 